Jessica Pepp

Uppsala University

(This is a draft of a chapter to be published in E. Michaelson and A. Stokke, eds., Lying. Oxford University Press.)

\title{
Truth Serum, Liar Serum, and Some Problems about Saying what You Think is False
}

\section{Untruthfulness}

Most philosophical analyses or definitions of lying have three parts. Take, for instance, Don Fallis's articulation of the "Traditional Analysis of Lying":

$\mathrm{S}$ lies to $\mathrm{H}$ iff:

1. S says that $\mathrm{p}$ to $\mathrm{H}$.

2. $\mathrm{S}$ believes that $\mathrm{p}$ is false.

3. $\mathrm{S}$ intends $\mathrm{H}$ to believe that $\mathrm{p}$ on the basis of $\mathrm{S}$ 's saying that $\mathrm{p}{ }^{1}$

Following James Mahon, we can call the conjunction of 1 and 2 the "untruthfulness condition," and 3 the "intention to deceive the addressee condition."2 The lion's share of philosophical work on the analysis of lying has focused on 3 and 1 . With respect to 3 , the central question has been whether an intention to deceive the addressee is required for lying, and if not, what must be added to 1 and 2-i.e., to untruthfulness - to get lying. ${ }^{3}$ Untruthfulness by itself is not sufficient for lying, since we often say things we do not believe in joking, and we are not lying in such cases. ${ }^{4}$ The interest in distinguishing lying from merely being untruthful is clear. What makes lying different from being untruthful in joking,

\footnotetext{
${ }^{1}$ Fallis, this volume.

2 Mahon (2015). In Mahon's taxonomy, 1 also includes the "statement condition" (that someone must make a statement) and the "addressee condition" (that the person making the statement must take himself to make it to someone).

${ }^{3}$ For a sampling of work in this vein, see Mahon (2008), Lackey (2013), Fallis (2009), Stokke (2013), Carson (2006), and Sorensen (2007).

${ }^{4}$ Saul (2012: 7-8) explains concisely this motivation for adding some further condition in the place of 3, where 3 itself is an obvious candidate.
} 
irony, or sarcasm also makes a critical moral difference. So it is important to understand what the former difference is.

With respect to 1 , the focus has been on the notion of saying (or stating, or asserting) that figures in the proper analysis of lying. In order to lie, one must say (state, assert) something, as opposed to, for instance, merely implying it. But there are many notions of saying (stating, asserting): which one captures the sense in which saying something opens up the possibility that one is lying (if other conditions are in place) $?^{5}$

Something that has received less attention in the discussion of lying is 2 , and how it combines with 1 to characterize what Mahon calls untruthfulness, or what we might loosely call "saying what one thinks is false". ${ }^{6}$ Untruthfulness (in this sense) is not merely saying something that is false, for that could happen due to error, with the speaker taking what she says to be true. In such a case, the speaker is incorrect, but she is not untruthful. Nor is saying something that is false even necessary for untruthfulness: if a speaker says something that she takes to be false but that is actually true, she is still untruthful. ${ }^{7}$ The target phenomenon here is a kind of conflict between one's thinking and one's speech. Emphasizing the centrality of this conflict to lying, Aquinas took the Latin word for lie, mendacium, to be apt in its suggestion of deriving from contra mentem dicitur ("said contrary to the mind"). ${ }^{8}$

In this paper, I will use the word "untruthfulness" to refer to this conflict between thought and speech that is the basis for lying. My aim is to show how stubbornly this conflict resists characterization. Clauses 1 and 2 of the Traditional Analysis of Lying constitute one traditional way of doing so, but in Section 2 I show how standard cases of unconscious or

\footnotetext{
${ }^{5}$ See, for instance, Saul (2012) and Stokke (2013). Some theorists take saying that $p$ to be a necessary but not sufficient condition for asserting that $p$, and take asserting that $p$ to cover both clause 1 of the Traditional Analysis and some preferred version of clause 3. (Fallis 2009 and Stokke 2013 are examples of this.) Following at least one normal practice in the debate on lying, I will use "saying," "asserting," and "stating" interchangeably. (For discussion see Saul 2012: 3.) Those who use "asserting" to refer to a sub-class of what "saying" refers to are using it in a different way than I am using it in this paper.

${ }^{6}$ There has been some attention to how the counterpart of 2 should be formulated in discussions of the analysis of insincerity. I will draw upon and make reference to some of this work as the paper proceeds. I believe that some of what I will say is relevant to the analysis of insincerity more broadly, as well as to lying specifically, but I will not argue for that extension here.

${ }^{7}$ Indeed, the dominant philosophical view going back to Augustine's treatise De Mendacio (circa 395 C.E.) seems to be that falsity of what is said is not required even for lying. For some contemporary endorsement of this, see (for instance) Saul (2012), Isenberg (1973), Faulkner (2013). Some philosophers maintain, against this, that falsity is required for lying (e.g. Carson 2006, Coleman and Kay 1981). There is some intuitive pull to the idea that lying requires that what is said be false. But for those who think so, the falsity of what is said is added as a separate condition from the untruthfulness condition, which involves a mismatch between one's speech and one's thinking. ${ }^{8}$ Summa Theologica, lines 1992b20-32. Aquinas does not mean this as an etymological suggestion about
mendacium. See Griffiths (2010) for discussion.
} 
divided belief challenge this analysis. In Sections 3-5 I use classic puzzles about belief from Gottlob Frege and Saul Kripke to show that suggested amendments involving assent/dissent instead of belief do not fare better. Further, I argue that attempts to save these analyses by appeal to guises or Fregean modes of presentation will also run into trouble. Sections 6-7 consider alternative approaches to untruthfulness that focus on (a) expectations for one's act of saying/asserting and (b) the intentions involved in one's act of saying/asserting. Here I introduce two new kinds of case, which I call "truth serum" and "liar serum" cases.

Consideration of these cases reveals structural problems with these intention and expectationbased approaches as well.

Taken together, the string of cases presented suggests that saying what you think is false is no less difficult and interesting a subject for analysis than lying itself. It is at least as pressing a matter for analyses of lying as the question of how lying should be distinguished from merely saying what one thinks is false (e.g., whether and in what way deception should enter into this). ${ }^{9}$ Further, tackling the question of what it is to say what you think is false (in the sense targeted with respect to lying) illuminates ways in which the study of lying is intertwined with fundamental issues in the nature of intentional action, as I explain in the concluding section 8 .

\section{The Belief Analysis}

Let me begin with the analysis of untruthfulness included in the Traditional Definition of Lying.

\section{$\underline{\text { Belief Analysis }}$}

$\mathrm{S}$ is untruthful to $\mathrm{H}$ iff:

1. S says that $\mathrm{p}$ to $\mathrm{H}$.

2. $\mathrm{S}$ believes that $\mathrm{p}$ is false.

\footnotetext{
${ }^{9}$ It also poses problems for variations on the traditional analysis requiring only that one does not believe what one says, rather than that one believe it to be false, or requiring only that one believe false what one communicates (including implications) rather than what one strictly says. For the former, see Carson (2006), Shiffrin (2014), Sorensen (2011). For the latter, see Meibauer (2011).
} 
The Belief Analysis has the problem that there are cases in which a speaker is untruthful in saying/asserting/stating something even though the speaker does not believe what she says to be false and indeed believes it to be true. Chan and Kahane (2011) give the example, which they adapt from Peacocke (1998), of a British professor whose hiring and recommendation-writing decisions make clear that "deep down" she believes that degrees from British universities are superior to those from foreign universities. However, this professor is not aware of her belief and judges on the basis of evidence that undergraduate degrees from other countries are equally good. Asked in a newspaper interview to compare British and American universities, she claims, out of a desire to fend off cuts to British higher education funding, "British universities are the best in the world," even though she judges that this is not the case.

It seems that the professor is lying, and thus being untruthful. But according to the Belief Analysis, she cannot be, since she does believe that British universities are the best in the world. Another way of describing the situation is that it is unclear or indeterminate whether the professor really believes that British universities are the best in the world, given that she both behaves as if they are and has judged that they are not. Despite it being unclear whether the professor believes this, it is clear that when she says in the interview that British universities are the best in the world she is being untruthful. This strains the Belief Analysis of untruthfulness. ${ }^{10}$

It might be objected that it is actually not so clear that the professor is being untruthful. Some may find it more certain that the Belief Analysis is correct than that the professor is lying. From this point of view, uncertainty about the satisfaction of clause 2 brings with it uncertainty about whether this is a lie. ${ }^{11}$ If this position attracts you, hold onto the Belief Analysis as you read on into Section 3. I think the considerations advanced there against a Dissent Analysis of untruthfulness will apply also to the Belief Analysis, and will be harder to reject on the grounds that the Belief Analysis is more robust than our intuitions about lying and belief in the relevant cases. I will return to this objection at the end of Section 3.

\footnotetext{
${ }^{10}$ It might be objected that the professor's having considered the evidence and judged that degrees from around the world are equally good is sufficient for her to believe what she says to be false, even if she also believes it to be true. So both sides of the Belief Analysis biconditional hold. But this sort of argument would require that if during the interview the professor instead expressed her judgment that university degrees from different countries are equal, she would be untruthful, since she (deep down) believes this to be false, even if she also believes it to be true. And this seems wrong.

${ }^{11}$ Thanks to an anonymous referee for this volume for pressing this objection.
} 


\section{The Dissent Analysis}

The case of the professor suggests that what matters for untruthfulness is not what people really, deep down believe ${ }^{12}$ but what they are consciously, while speaking, disposed to think or judge. One way of putting this is in terms of mentally assenting to a claim, which is roughly the mental action of affirming the claim in one's own thinking when one considers the question of whether it is true. Being truthful may then be analyzed as being disposed to mentally assent to what one is saying, while being untruthful may be analyzed as being disposed to dissent mentally from what one says. ${ }^{13}$ This gives us:

\section{Dissent Analysis}

$\mathrm{S}$ is untruthful to $\mathrm{H}$ iff:

1. S says that $\mathrm{p}$ to $\mathrm{H}$.

2. $\mathrm{S}$ is disposed to mentally dissent from $\mathrm{p}$.

This captures the case of the professor: she may believe that British universities are the best in the world, but when she considers this consciously, she does not judge it to be true (per the description of the case). I take this to entail that she is disposed to dissent from it mentally. Thus, she is untruthful in the interview according to the Dissent Analysis.

\footnotetext{
${ }^{12}$ Sorensen (2011) calls this "deep belief."

${ }^{13}$ Another possibility would be to analyze untruthfulness as not being disposed to mentally assent to what one says. This would make untruthfulness encompass saying something that one is not disposed to assent to, but also not disposed to dissent from. For instance, it might encompass saying something one is unsure of. Philosophers writing on lying disagree about whether one may lie in this way (e.g. Carson (2006) and Sorensen (2011) maintain that one may while Saul (2012: 20) thinks this would be bullshitting, not lying.) Chan and Kahane (2011) consider (and ultimately reject) an account of insincerity in terms of not being disposed to mentally assent to what one says. Stokke (2014) advocates an account of insincerity in terms of not mentally assenting to what one says, and defends it against Chan and Kahane's criticisms. The focus on non-assent makes sense in discussions of insincerity, which includes bullshitting. I am inclined to think that lying requires something stronger, so I have chosen to formulate the Dissent Analysis in terms of being disposed to dissent. However, the same kinds of problems that I will raise for the Dissent Analysis apply, mutatis mutandis, to accounts formulated in terms of lack of mental assent.
} 
Nonetheless, the Dissent Analysis of untruthfulness can be challenged in much the same way as the Belief Analysis was challenged. It can be challenged on the grounds that there are cases in which it is not clear whether or not the speaker is disposed to dissent from what she says, yet it is clear that she is untruthful.

Some examples of this are classic cases of ignorance of identity, such as the case (introduced by Frege (1892/1997)) of someone who does not know that a certain heavenly body she sees early in the evening, which she calls "Hesperus," is the very same entity that she sees late in the morning, which she calls "Phosphorus." Chalmers (2012) imagines the following scenario:

Suppose that Sue knows that the morning star is a planet but believes that the evening star is not a planet. Like others in her community, she associates 'Hesperus' with the evening star and 'Phosphorus' with the morning star. Intending to deceive John, she says 'Hesperus is a planet'. (44)

Clearly, Sue is insincere and untruthful in this scenario. ${ }^{14}$ She says that Hesperus is a planet. Is she disposed to dissent from this? That depends on what "this" is. If it is simply the ascription of an attribute to an object (i.e., if the applicable notion of saying is "de re" or if what is said is a "Russellian" proposition constituted by an object - the planet Venus - and the property of planet-hood), then it is not clear whether Sue is disposed to dissent from the ascription of planet-hood to Venus, or from the Russellian proposition predicating planethood of Venus. Given that it is clear that Sue is untruthful, this puts pressure on the Dissent Analysis.

We might describe the situation as follows: Sue is disposed to dissent from the proposition when it is expressed using the sentence "Hesperus is a planet" but not when it is expressed using the sentence "Phosphorus is a planet." This might suggest the following revision of the Dissent Analysis:

\section{Dissent-from-Sentence Analysis}

$\mathrm{S}$ is untruthful to $\mathrm{H}$ iff:

1. S says that $\mathrm{p}$ to $\mathrm{H}$ using the sentence ' $\mathrm{p}$ '.

2. $\mathrm{S}$ is disposed to mentally dissent from $\mathrm{p}$ when expressed using the sentence ' $\mathrm{p}$ '.

\footnotetext{
${ }^{14}$ Those who think lies must be false may think this is not a lie because what Sue says is true. Even if this is correct, Sue is still being untruthful: she displays the conflict between thought and speech that is the basis for lying, even if the truth of what she says disqualifies it from being a lie. (See Section 1.)
} 
The Dissent-from-Sentence Analysis would allow that Sue is untruthful to John, since she is disposed to dissent from the proposition she asserts when it is expressed using the sentence she uses to assert it. ${ }^{15}$

But this solution does not work in general, as can be seen by considering Kripke's (1979) case of Peter, who takes there to be both a politician, Paderewski, and a different man, a musician, Paderewski, when in fact the politician and the musician are one and the same man, Paderewski. Peter believes that Paderewski, the politician, is not musically talented, but that Paderewski, the musician, is musically talented. Like Sue in Chalmers' example, Peter might say, "Paderewski is musically talented," intending to deceive John about the politician. Here Peter is clearly untruthful, ${ }^{16}$ although it is not clear whether he is disposed to dissent from what he says when it is expressed using the sentence he uses to say it.

The case of Peter also shows that the solution is not to revise the Dissent Analysis so that it appeals to actual dissent rather than to a disposition to dissent. Consider the following revision:

\section{Non-dispositional Dissent-from-Sentence Analysis}

$\mathrm{S}$ is untruthful to $\mathrm{H}$ iff:

1. S says that $\mathrm{p}$ to $\mathrm{H}$ using the sentence ' $\mathrm{p}$ '.

2. S actually mentally dissents from $\mathrm{p}$ expressed using the sentence ' $\mathrm{p}$ '.

For suppose that Peter says truthfully to John "Paderewski is musically talented." He might at the very same time be consciously dissenting from the very same sentence in thought. He might be thinking how funny it is that a different man by the same name as the musically talented musician is so untalented musically. Here Peter says to John that Paderewski is musically talented, using a sentence from which he is actually mentally dissenting. And yet, in this case Peter is truthful.

Notice that the same problems as outlined here for the Dissent Analysis will arise for the Belief Analysis. Consider Chalmers' example again. Sue says that Hesperus is a planet. Does Sue believe that Hesperus is a planet? That depends on what is involved in believing that Hesperus is a planet. If it is believing a Russellian proposition predicating planethood of

\footnotetext{
${ }^{15}$ Sorensen (2011) suggests an analysis of lying in this vein prompted by discussion of Kripke's (1979) case of a subject, Pierre, who assents to "Londres est jolie" but dissents from "London is pretty."

${ }^{16}$ Again, he displays the untruthfulness required for a lie, even if the truth of what he says disqualifies it from being a lie.
} 
Hesperus, or if it is simply believing, of the object Hesperus, that it is a planet, then Sue does believe this. Given that Sue also believes it false that Hesperus is a planet, it is at least not clear whether or not she believes that Hesperus is a planet. Yet, intuitively, Sue is untruthful to John.

Recall the objection to my criticism of the Belief Analysis that I posed at the end of Section 2. According to this objection, the truth of the Belief Analysis is more certain than the presence of untruthfulness in a case like Peacocke's Professor. Someone holding this view might also think that our verdict on whether Sue is untruthful is held hostage to our verdict about what she believes.

But there are similar cases where this is implausible. Imagine that Sue is riding the bus on her way to work and notices a man sitting many rows ahead of her who has a bag full of beach gear beside him. Sue, who is rather judgmental, thinks to herself, "That man is skipping work today to go to the beach. What a lazy slacker." Later on that day, while Sue is at work, her boss, John, calls her to say that he is out sick and would like an update on how things are going at work. Sue, who is also rather treacherous, sees an opportunity to make trouble for Tom, her co-worker and main professional rival. Inspired by her sighting of the man on the bus that morning, she tells her boss that Tom has skipped work that day to go to the beach, even though she saw Tom toiling away in his office down the hall just minutes earlier.

It seems clear that Sue is lying, and so is untruthful. But now let us add a predictable twist to the story: as a matter of fact the man Sue saw on the bus was Tom, though she did not recognize him from behind. Tom had beach gear with him because he had borrowed it from another co-worker for a weekend excursion and was bringing it to work in order to return it. Given this, for the same reasons as in the Hesperus-Phosphorus case, there is a question about whether or not Sue believes what she told her boss. For she believes that the man she saw on the bus this morning-Tom-has skipped work to go to the beach. But this does not weaken at all the conviction - at least, it does not weaken my conviction - that Sue is lying. This suggests that the Belief Analysis is not in general more certain than intuitions about lying (and thus untruthfulness) in cases where it is unclear whether the speaker believes what she says.

The objector might hold that the strength of the intuition that Sue is untruthful simply reflects the strength of the intuition that Sue does not believe what she says, in spite of the puzzle introduced by her failure to recognize the man on the bus as Tom. This seems wrong to me: even a philosopher thoroughly versed in such puzzles and filled with uncertainty about 
what Sue believes in this situation is bound to agree that Sue lies to John. But perhaps such philosophical uncertainty would only be masking an ordinary-life certainty that Sue believes it false that Tom skipped work. Perhaps it really is the latter belief that drives the intuition that Sue is lying. If so, then this objector is now in the same position as the proponent of the Dissent Analysis. She needs to endorse an account of what Sue says, for purposes of characterizing lying, on which it is clear that Sue does not believe what she says. This cannot be a de re or Russellian notion of what is said.

\section{Preserving the Dissent (or Belief) Analysis via Guises}

One might try to preserve the spirit of a Dissent or Belief Analysis of untruthfulness while maintaining that the relevant notion of "what is said" is Russellian by employing the notion of guises. The Dissent Analysis could be revised as follows:

\section{Dissent-Under-a-Guise Analysis}

$\mathrm{S}$ is untruthful to $\mathrm{H}$ iff:

1. S says that $\mathrm{p}$ to $\mathrm{H}$ under guise $\mathrm{G}$.

2. $\mathrm{S}$ is disposed to mentally dissent from $\mathrm{p}$ under $\mathrm{G}$.

A guise, in the sense of Salmon (1986/1991), may be glossed loosely as a subject's way of grasping a proposition, or way of thinking about a thing. So the Dissent-Under-a-Guise Analysis of untruthfulness can allow that Peter says the same thing (asserts the same proposition, ascribes the same attribute to the same individual) both when he says, "Paderewski is musically talented," truthfully and when he says it untruthfully. The difference between these cases, a guise theorist would claim, is that he thinks of or grasps what he says in different ways in each case. When he grasps it in the way he does in the untruthful case, he is disposed to dissent from it. When he grasps it in the way he does in the truthful case, he is not disposed to dissent from it.

This is not obviously correct, though. Much depends on what guises are, and the notion is under-described. ${ }^{17}$ Let's allow that Peter grasps the proposition he asserts in some different ways in the truthful versus the untruthful cases: for instance, in the truthful case he thinks of

\footnotetext{
${ }^{17}$ As Salmon acknowledges (1991: 126).
} 
Paderewski as a musician, while in the untruthful case he thinks of Paderewski as a politician. Even so, he also grasps the proposition he asserts in a single way in the truthful and untruthful cases: in both cases he thinks of Paderewski as Paderewski-i.e., via the single name "Paderewski."18 This also happens when subjects are not confused but simply change over time in what they attribute to things. On first hearing of the Evening Star, one may take it to be a star, and so think of it as a star. If one later learns that it is not a star, but a planet, one will cease thinking of it as a star and start thinking of it as a planet, all the while continuing to think of it as the Evening Star.

Thus, when Peter untruthfully says, "Paderewski is musically talented," it is not obvious that he is disposed to dissent from what he says under the guise under which he says it. At least under one guise under which he says it - the guise involving thinking of Paderewski as Paderewski - it is not clear whether he is disposed to dissent or not.

A guise theorist might reply that we need to consider a richer guise: one that includes not only the name by which Peter thinks of Paderewski, but his thinking of Paderewski as a politician. Then, in the untruthful case, Peter says that Paderewski is musical under a guise that involves thinking of Paderewski as Paderewski and as a politician. Under this guise, he is (clearly) disposed to dissent from what he says.

This is not sufficient, though, since Peter might come to believe that the musically talented Paderewski is also a politician, albeit a distinct one from the non-musically talented Paderewski. In this scenario, Peter could still say, "Paderewski is musically talented" untruthfully, even though it is now unclear whether he is disposed to dissent from what he says under the guise that involves thinking of Paderewski as Paderewski and as a politician.

So the guise must be even richer. To see how rich it needs to be, consider that Peter might come to differentiate "the two Paderewskis" (as he might put it) in only one respect. It might be that the only difference he draws between them is that one is musically talented and the other is not. Even in such a scenario, Peter can say untruthfully, "Paderewski is musically talented." If his untruthfulness is a matter of his being disposed to dissent from what he says under the guise under which he says it, then the only way to ensure that he is clearly disposed to dissent is by making it part of the guise under which he says what he says that Paderewski is thought of as not musically talented.

Let's introduce the notion of a "total guise": roughly, the complete way in which a subject grasps something he says (if you like, a proposition). We can then propose:

\footnotetext{
18 This point is made by Sainsbury (2010).
} 


\section{Dissent-Under-a-Total-Guise Analysis}

$\mathrm{S}$ is untruthful to $\mathrm{H}$ iff:

1. S says that $\mathrm{p}$ to $\mathrm{H}$ under total guise TG.

2. $\mathrm{S}$ is disposed to mentally dissent from $\mathrm{p}$ under TG.

Now the guise theorist may claim that in the untruthful case Peter is disposed to dissent from what he says under the total guise under which he says it. By contrast, he is not disposed to dissent from what he says under the total guise under which he says it in the truthful case. We are no longer pulled in two directions as to whether clause 2 is satisfied. However, a different sort of worry arises for this account, and it illustrates a way in which all of the analyses so far considered are operating with an incorrect picture of untruthfulness. I will discuss the worry in Section 6. First, in Section 5, I will consider another option for preserving the Belief or Dissent Analysis: treating what is said in a "Fregean" rather than a "Russellian" way.

\section{Preserving the Dissent (or Belief) Analysis via Fregean Propositions}

Fregean propositions are constituted not by objects and properties, but by modes of presentation, or ways of thinking of, those objects and properties. A Fregean view would hold that "what the speaker says" should be understood (roughly) as a content capturing the way she thinks of the objects she refers to and the properties she predicates of them. The satisfaction of clause 2 would then depend on whether the speaker believes (or is disposed to assent to or dissent from) this content that reflects her ways of thinking. For the same reasons that the guise-based analysis was driven to make use of total guises, so the Fregean proposition-based analysis will be driven to make use of what we might call "total propositions": propositions that capture as completely as possible an agent's internal perspective on what she says and believes. ${ }^{19}$

The commitment to such extremely fine-grained propositions as the objects of both assertion and belief is a substantial one. Development and criticism of such views in the

\footnotetext{
${ }^{19}$ Chalmers' (2011) "enriched propositions" would fit this bill.
} 
literature is extensive and intricate, and there is not space here to engage with it in detail. ${ }^{20} \mathrm{I}$ cannot offer knockdown arguments against applying such views in the analysis of lying. But I would urge that before taking on such heavy theoretical commitments in order to give an analysis of lying, it would be worth exploring other options. Beyond this general methodological point, I will note that a Dissent-to-a-Total-Proposition Analysis of untruthfulness would be subject to the same worry as the one I will raise for the DissentUnder-a-Total-Guise Analysis in Section 6. Before coming to that, let me point out one challenge specific to the Fregean approach to the analysis of lying.

It would seem that if it is possible for a speaker to lie to her addressee, then what the speaker says should be something the addressee is at least capable of understanding. For instance, it is doubtful that a speaker can lie to a hearer in a language the hearer does not know. (Although the speaker might try to lie to the hearer if the speaker does not realize that the hearer does not know the language.) And the sorts of propositions that capture someone's complete way of thinking what she thinks (or says) are generally supposed not to be shared (or in some cases, even sharable) between people who nonetheless communicate with one another.

Consider the case of Peter. His ways of thinking of Paderewski are likely different from those of his interlocutor John (especially if John is not confused in the way Peter is). This means that John cannot grasp the total proposition that Peter asserts because he is not able to think of Paderewski in the same way that Peter does in making the assertion. But John seems able to understand what Peter says: that Paderewski, a man they both are familiar with, is not musically talented. Hence it is not clear that the total proposition associated with Peter's utterance is what he says for purposes of assessing whether he lies.

There are ways of addressing this issue. For instance, one might argue that the possibility of communication does not require the addressee to be able to come to grasp or think the exact same total proposition as the speaker expressed, but to be able to grasp or think a total proposition that is sufficiently similar to it. Then one might hold that the total proposition John can grasp as a result of Peter's utterance is sufficiently similar to the one Peter expresses, so Peter's total proposition is not after all uncommunicable to John. How satisfying this is depends on working out the notion of sufficient similarity (or propositions being "coordinate" with one another, in Chalmers' terminology $\left.{ }^{21}\right)$. Otherwise the notion is

\footnotetext{
${ }^{20}$ Prominent views in this vein are developed in Jackson (1998) and Chalmers (1996), (2002), (2006), (2011).

${ }^{21}$ Chalmers (2011).
} 
just a placeholder for the needed explanation of how an addressee can understand a speaker's expression of a total proposition the addressee is incapable of entertaining, by entertaining a different total proposition. This is a promissory note that a Fregean approach to untruthfulness must make good on.

\section{Intentions, Expectations, and How to Picture Untruthfulness}

The foregoing discussion of the Fregean approach is intended more as a warning about potential difficulties than as an argument against it. And I have yet to offer any argument against the Dissent-Under-a-Total-Guise Analysis. In this section, while falling well short of a decisive argument against either approach, I will try to convey my reasons for thinking that these are not the most promising ways to understand the untruthfulness involved in lying.

I will use counterexamples to the variously modified Dissent and Belief Analyses to do this. But as intuitions about these examples are bound to vary, let me begin by explaining the point I hope to illustrate with them. This is that untruthfulness - the conflict between thought and speech that is the basis for lying - is not a matter of being related in a certain way to an abstract proposition or guise via one's speech and also being related in a certain way to that same abstract entity via one's beliefs or dispositional psychology. Clauses 1 and 2 in the Traditional Analysis and in the revisions I have considered reflect this picture. They portray the doxastic state involved in lying as potentially unconnected to the relevant act of saying, other than by the fact that they share a content. If you count as saying that $\mathrm{p}$, and you count as believing that $\mathrm{p}$ is false (or being disposed to dissent from $\mathrm{p}$, being disposed to dissent from $\mathrm{p}$ under a certain guise, etc.), then you count as untruthful, regardless of how the saying and the believing are (or are not) linked up.

Contrary to this, untruthfulness seems to involve a tight connection between one's act of saying something and the thinking that motivates and sustains the act. Speaking against one's mind in the way that makes lying possible seems to be a matter of one's intentions or expectations with respect to a particular act of speaking, and not only as concerns the deception of others. A first pass analysis would be that one is untruthful iff one says something intending to say something one believes to be false, or says something with the expectation that one will say something false. (This is meant to encompass cases of irony, 
sarcasm, deceptive lying, and bald-faced lying, but not cases of mis-speaking or failures of reason.)

To motivate further the need for this change of picture, let us move on to a case. Imagine an anxious dinner host who has been informed that one of his guests, Isaac, is a vegetarian. He doesn't know Isaac well, so one of the primary ways in which he thinks of Isaac is as a vegetarian. Being the anxious type when it comes to entertaining, he's worked hard to ensure there are sufficient vegetarian options at the dinner. He's highly sensitive to the feelings of his guests and wants everyone to feel welcome. As a result, upon noticing that the other guests repeatedly neglect to pass the steak to Isaac, he says, "Isaac might like some meat."22 The host is actively thinking of Isaac as a vegetarian, as someone who does not eat meat. That is surely part of the total guise under which he says that Isaac might like some meat. The host is disposed to dissent from what he says under this guise: he would dissent in calmer, more reflective situations. But he is anxious and addled, and doesn't perform the needed bit of reasoning. Still, he is not lying, nor is he untruthful.

This might even be a case in which the host is actually dissenting from what he says under the total guise. He might be actively reminding himself that Isaac is a vegetarian, Isaac does not want any meat, while at the very same time his desire for the food to be doled out fairly to all leads him to ascribe being a candidate for wanting meat to Isaac, both mentally and out loud in language. Here he consciously mentally dissents from what he says, under the total guise under which he says it. Still, he is not lying, nor is he untruthful.

As presented, the case of the anxious host challenges the sufficiency, rather than the necessity, of the Dissent-Under-a-Total-Guise Analysis. Given this, it may be a weak challenge, since the target of the analysis, untruthfulness, is itself only a necessary (not sufficient) condition for lying, and the clearest intuition we have here is that the host is not lying. Hence, it might be suggested that in this case the host is untruthful, but is not lying due to the non-satisfaction of some version of clause 3 . However, most candidates for clause 3 are designed to prevent cases of joking, irony, sarcasm, and the like from counting as lies in a given analysis, and it is not immediately clear that they would apply to the host's statement, which is made in earnest.

Furthermore, there are cases like that of the anxious host that do challenge the necessity of the analysis. Imagine the host is in the same sort of anxious muddle as in the original

\footnotetext{
${ }^{22}$ If this utterance strikes you as a suggestion of the kind "You might want to watch the sunset if you have time" rather than as an assertion or statement of the kind that could be the basis for a lie, then imagine, instead, that the host says, "Isaac needs the meat."
} 
example, but in this case, in addition to being worried that Isaac, the vegetarian, has not been passed the meat, he (being socially hypersensitive) also notices that another guest has grown uneasy about the same omission. The host acts quickly to preserve the guest's sense of ease by whispering to her a white lie: "It's okay, he doesn't want any." If we allow, as seems to me possible, that the host says this under a total guise that involves thinking of Isaac as a vegetarian and that he is not disposed to mentally dissent from what he says under this guise (he is disposed to assent to it), then the intuition that this is a (white) lie suggests that the Dissent-Under-a-Total-Guise Analysis does not contribute to necessary conditions for lying.

The Dissent-Under-a-Total-Guise Analysis of untruthfulness misses the mark on these cases because people sometimes fail to reconcile the way they are thinking of something with what they are saying about it. Thus, the fact that one is disposed to dissent from what one says, grasped in the particular way in which one grasps it in saying it, does not entail that one is being untruthful. Nor, even, does the fact that one is actually dissenting from what one says, grasped in that same particular way. Conversely, one may be untruthful even if one is not disposed to dissent from what one says, grasped in the particular way in which one grasps it in saying it.

\section{The Belief-About-Action Approach}

I commented above that untruthfulness seems to be a matter of the intentions and expectations bound up in a particular act of speaking, rather than being the conjunction of a doxastic state and a speech act with the same content. This comment can be divided into two suggestions, one focused on belief and expectations, the other focused on intentions.

The first suggestion is to shift focus from the speaker's belief (or disbelief) in what she says to her beliefs or expectations about the saying or assertion itself. ${ }^{23}$ I will call this the "Belief-About-Action Approach." The second suggestion is to shift focus from the cognitive attitudes of belief and assent/dissent to conative states of intention or motivation. ${ }^{24}$ I will call this the "Intention Approach." I will begin in this section and the next with the Belief-About-

\footnotetext{
${ }^{23}$ This is parallel to a suggestion of Chalmers that those wishing to preserve a Russellian view of what is said might re-characterize sincere assertion as obtaining "if the speaker believes that the assertion expresses a true proposition." (45)

${ }^{24}$ This is in some ways parallel to Chan and Kahane's (2011) advocacy of not identifying insincerity with any particular kind of cognitive attitude toward a proposition, and focusing instead on what motivates the speaker in making a particular assertion. My development of the suggestion will be quite different from theirs, however.
} 
Action Approach, and take up the Intention Approach in Section 9. We will see that characterizing the intentions or expectations involved in untruthfulness is a difficult matter.

Here is a first-pass Belief-About-Action analysis of untruthfulness:

\section{Belief-About-Action Analysis 1:}

$\mathrm{S}$ is untruthful to $\mathrm{H}$ iff:

1. S says something/makes an assertion/makes a statement.

2. $\mathrm{S}$ believes that her saying/assertion/statement is false. ${ }^{25}$

This analysis also faces Paderewski type problems, only now focused on the assertion itself rather than on what the assertion is about. Suppose two children are accused of stealing a pie from the kitchen. The thief immediately declares, "I didn't do it," and due to an echo it sounds to her as though her co-defendant utters the same sentence at the same time. It seems correct to say that the thief believes that what she takes to be her co-defendant's assertion (which is really her own assertion echoed back at her) is true (if you like, expresses a true proposition), and that it is not false (if you like, does not express a false proposition). It also seems correct to say that she believes that it (her own assertion) is false (expresses a false proposition). Thus it is not clear whether or not she believes that her own assertion is false. But it is clear that her assertion is untruthful.

This worry might be addressed by changing the suggested analysis so that it focuses on the speaker's belief about what she is doing, rather than on her belief about a particular assertion, as follows:

\section{Belief-About-Action Analysis 2:}

$\mathrm{S}$ is untruthful to $\mathrm{H}$ iff:

1. S says something/makes an assertion/makes a statement.

2. S believes that she is saying something/making an assertion/making a statement that is false.

\footnotetext{
${ }^{25}$ One might want to gloss believing that a saying/assertion/statement is false as believing that it expresses a false proposition, as in the suggestion from Chalmers mentioned in footnote 23 . There is no need to commit to this gloss, though, and it is important to distinguish believing that an action is a false saying, stating, or asserting from believing that a proposition that happens to be expressed through this action is false, lest the Belief-AboutAction Analysis collapse into the Belief Analysis.
} 
The problem with this is that the speaker may believe she is - presently - making a false assertion without believing, of some particular assertion she is making, that it is false. This is possible, for instance, if a speaker is capable of making two assertions simultaneouslyperhaps, one signed to a deaf interlocutor and one spoken to a hearing one. This speaker might be truthful to the deaf interlocutor even though she simultaneously believes that she is saying something false (i.e., to the hearing interlocutor). To be untruthful, she must (at least) perform an act of speaking and believe de-that act of speaking that it is false.

To pursue the Belief-About-Action approach, it would need to be spelled out how one must think of one's action and attribute falsity to it in order have the requisite kind of belief. ${ }^{26}$ But regardless of how this is spelled out, a further worry arises for the Belief-About-Action approach. This is the worry that an assertion may be clearly untruthful, while it is not clear whether the speaker believes her action is a false asserting.

\section{Truth Serum and Liar Serum}

I will illustrate this by appeal to a pair of cases in which speakers' intentions and beliefs about their speech actions diverge. First, suppose a jewel thief is being interrogated by the authorities, and is convinced that a "truth serum" has been administered to her. In fact, no such serum has been administered to her. The interrogators demand to know the location of the jewels. The jewel thief wants to tell them a wrong location, but she believes the truth serum is going to make this very difficult. She believes that the truth serum works so as to make it seem to her, as she is planning what to say and speaking, that what she is saying is false, when in fact she is in the process of expressing her true belief. She does not think the truth serum is 100 percent effective, though, so she thinks it is worth at least trying to tell the interrogators a wrong location. So she tells them that the jewels are in location $\mathrm{X}$, where she does not take the jewels to be. She does not believe that this action is a false assertingindeed, she thinks it is very unlikely to be a false asserting. She believes it most likely that she has in fact revealed to the interrogators the true location of the jewels, even though it

\footnotetext{
${ }^{26}$ For instance, perhaps it is required that one's thinking of one's action not be perceptually based; that it be "non-observational" in the sense of Anscombe (1963: 13-15). Or perhaps one's thinking of one's action must be based in a special kind of perception we have "from the inside." (See Pickard 2004.)
} 
seems to her as though she has lied. Nonetheless, her assertion is a lie and therefore untruthful.

It can also be that an assertion is clearly truthful, while the speaker believes that the assertion is a false assertion. Take the reverse idea of a truth serum: a "liar serum." Suppose a speaker believes (wrongly) that she has been given a drug that will make her lie, regardless of her efforts to tell the truth. Continuing with the jewel thief story, let's say she was a witness to the crime and believes the jewel thieves have injected her with this serum to prevent her from revealing what she knows to the police. As with the truth serum example, she believes that the liar serum works so as to make it seem to her, as she is planning what to say and speaking, that what she is saying is true, when in fact she is in the process of saying something she takes to be false. Nonetheless, as in the truth serum example, she does not believe that the liar serum is 100 percent effective, so she tries to be honest (and, in fact, succeeds, since no such serum has actually affected her). She tells the police, "There were six of them in the getaway car." It seems clear that she is not untruthful here, although she believes, of her assertion, that it is false.

This worry about the Belief-About-Action approach is reminiscent of discussion in the philosophy of action about the principle that doing something intentionally entails believing that one is doing it. ${ }^{27}$ This principle is threatened by cases of people intentionally doing things that they do not believe they are doing. The case of the jewel thief and the truth serum seems to be of this ilk: the jewel thief does not believe she is making a false assertion, yet she does so-makes a false assertion - intentionally. The case of the witness and the liar serum is the reverse: the witness believes she is making a false assertion, but whether she is or is not making a false assertion (she may be in error about the number of thieves), she does not do so intentionally. This might suggest that a more promising analysis of untruthfulness would be in terms of making a false assertion intentionally. This brings us to the Intention Approach.

\section{The Intention Approach}

Here is an initial analysis suggested by the Intention Approach:

\footnotetext{
${ }^{27}$ An important source is Anscombe's (1963) claim that intentionally doing something entails knowing nonobservationally that one is doing it. Some later writers defend the more modest claim that intentionally doing something entails believing that one is doing it. (See, for instance, Harman 1986 and Setiya 2008.)
} 


\section{Intentional Action Analysis:}

$\mathrm{S}$ is untruthful to $\mathrm{H}$ iff:

$\mathrm{S}$ intentionally says something false/makes a false assertion/makes a false statement to $\mathrm{H}$.

A problem with this suggestion is that an assertion may be untruthful even though it is true. ${ }^{28}$ Since one cannot intentionally make a false assertion if one does not make a false assertion at all, the suggested analysis would not accommodate true but untruthful assertions.

To maintain that there may be untruthful but true assertions, untruthfulness might be treated not as a matter of intentionally making a false assertion, but as a matter of making an assertion with the intention of making a false assertion.

\section{Acting-with-the-Intention Analysis:}

$\mathrm{S}$ is untruthful to $\mathrm{H}$ iff:

$\mathrm{S}$ says something/makes an assertion/makes a statement to $\mathrm{H}$ with the intention of saying something false/making a false assertion/making a false statement.

To evaluate this, I need to distinguish two kinds of case in which speakers are untruthful. I will call them "Acts of speech aimed at falsity" and "Acts of speech accepting falsity."

\section{Acts of speech aimed at falsity}

In this kind of case, it is part of the speaker's aim to make a false assertion. Here are a few of examples of this kind of case:

A) The guards come looking for my friend, the escaped prisoner. They interrogate me. In making an assertion in answer to them, my aim is to assert something with respect to the subject matter of my friend's location (nothing in particular, though the specifics of the case will no doubt recommend some things over others) that is not in fact true. My aim is to avoid telling them the truth about where he is.

B) I am called to testify in the trial of A for the murder of B. Everyone knows A did it, I know they all know, they all know I know, etc. I am asked to say where A was the night of B's murder. My aim is to assert something with

\footnotetext{
${ }^{28}$ See Section 1.
} 
respect to the subject matter of A's location on the night of B's murder (nothing in particular, though the specifics of the case will no doubt recommend some things over others) that is not in fact true. My aim is to avoid telling them the truth about where he was-i.e., not to say he was at B's house.

C) I enjoy lying for its own sake. On most occasions when I speak, I try to say something false. Upon meeting Mr. J on the street, I come up with: "Hi, Mr. J! I was just having coffee with the Queen.” My aim is to assert somethinganything at all-that is false. ${ }^{29}$

\section{Acts of speech accepting falsity}

In this kind of case, the speaker's aim is not to say something false but to assert a particular thing. Here are a couple of examples.

A) I am in a conversation where everyone is bragging about their accomplishments. It occurs to me that it would be cool if I received a $\mathrm{PhD}$ at age 10 and could tell them this. I reflect, sadly, that I did not do this. But I desire to impress them by making them think I got a PhD at age 10 , so I say, "I got a $\mathrm{PhD}$ at age 10.”

B) I train all year to try to run a mile in under 5 minutes. I gather a bunch of friends to time me. I come in at 5:25, all the watches agree. I know I have not met my goal, my friends know I have not, we all know each other knows, etc. But I am a sore loser and really want to be able to say I broke the 5 minute mile, so I do say it, whenever the topic of exercise or sport comes up. I feel that I worked so hard, I deserved to succeed. My casual claims that I broke the 5 minute mile hang in the air, passive-aggressively challenging anyone to say different.

In cases of the first kind, it seems clear that speakers make assertions with the intention of making false assertions. It is part of their aim in making these assertions that the assertions be false. Part of their aim would be thwarted if their assertions turned out to be true.

But many if not most lies are of the second kind. In this kind of case, it is no part of the speaker's aim in making the assertion that the assertion be false. The speaker's aim of asserting a particular thing would be just as well satisfied if their assertion were true. In these

\footnotetext{
${ }^{29}$ This is the type of lying practiced by what Augustine called the "real liar." It is an "unmixed lie," "done through only lust of lying and deceiving." (De Mendacio, section 25) I thank Andreas Stokke for pointing out the connection to me.
} 
cases, it is much less clear that speakers make assertions with the intention of making false assertions.

At least, this is much less clear if making an assertion with the intention of making a false assertion is different from making an assertion in or with the belief that it is a false assertion. These must be different if the problems of the previous section are to be avoided. One way of differentiating performing an action with the intention of X-ing from performing an action with the belief that one is X-ing (or will X) can be found in Bratman's (1987) discussion of the case of intending to run a marathon and believing that one will thereby wear down one's sneakers. Bratman's view is that if in fact one runs the marathon and wears down one's sneakers by doing so, then:

- One intended to run the marathon.

- One ran the marathon intentionally.

- One did not intend to wear down one's sneakers.

- One did not run the marathon with the intention of wearing down one's sneakers.

- But, at least if certain other conditions are satisfied, one did wear down one's sneakers intentionally.

In Bratman's (now fairly standard) taxonomy, the difference between running the marathon with the intention of wearing down one's sneakers and running the marathon with the belief that one is wearing down (or will wear down) one's sneakers is that acting with an intention of $\mathrm{X}$-ing entails endeavoring to $\mathrm{X}$, whereas acting with a belief that one is $\mathrm{X}$-ing does not entail endeavoring to $\mathrm{X}$. Endeavoring to $\mathrm{X}$ in acting requires that it be part of one's aim in acting to X. X-ing must be one of the purposes or goals one tries to achieve in acting, and must guide one's behavior accordingly. If I endeavor to hit a certain target, then "In a normal case this means that, other things equal, I will be prepared to make adjustments in what I am doing in response to indications of my success or failure in hitting it. I will be prepared to adjust the direction in which I am shooting in response to indications of the movement of the target and in ways believed by me to promote that goal." (129)

It is evident that wearing down one's sneakers is not (at least in the case as envisioned) something one endeavors to do in running a marathon. Wearing down her sneakers is not part of the marathoner's aim. She is not disposed to adjust her stride midway in response to indications that her stride so far has not been wearing her sneakers down. She is not disposed to rub the soles against a pumice stone if the end of the race nears and the sneakers are not worn down. (136) 
Similarly, in the case of Acts of Speech Accepting Falsity, speakers do not endeavor to make false assertions in making their assertions. Making false assertions is not part of their aim. They are not disposed to change their assertions mid-speech if they find out that they are going to be true. They are not disposed to work to change the state of the world to ensure the falsity of the assertions they are in the process of making. In Bratman's taxonomy, then, many if not most untruthful assertions are not assertions made with the intention of making a false assertion.

Of course, one does not have to accept Bratman's taxonomy. But if one wants to maintain that untruthful assertions of the second kind are made with the intention of making a false assertion, where this is different from their being made with the belief that the assertion is a false assertion, one needs to say something about in what the difference consists.

A suggestion in this direction might be found in Bratman's judgment that although the marathoner does not run the marathon with the intention of wearing down her sneakers, she does wear them down intentionally in running the marathon. Bratman takes this to be clearest in a case where (i) the runner consciously notes that she is wearing down the sneakers (or will wear them down) as she is running, and (ii) wearing down the sneakers is in some independent way significant to the runner, e.g. The sneakers are a family heirloom. (123)

Making a false assertion often has these features in the kinds of case under discussion. Speakers typically notice consciously that they are making a false assertion (though as discussed earlier, this does not seem required for untruthfulness). Making false assertions is also of independent significance: speakers are sensitive to various moral or practical reasons to avoid it. So we might want to say that an assertion is untruthful iff the speaker, in making it, intentionally makes a false assertion.

But of course, this is just the Intentional Action Analysis again, whose problems have already been noted. In order to use the notion of intentionally making a false assertion in an analysis of untruthfulness, making a false assertion has to be subtracted. Endeavoring to make a false assertion also has to be subtracted, since in Acts of Speech Accepting Falsity, speakers do not endeavor to make a false assertion. But what is left seems to be mostly one's belief that, in saying something/making a statement/making an assertion, one is saying something false or will say something false.

We have already seen the problems with analyzing untruthfulness in terms of a speaker's belief that in saying something she is saying or will say something false. So it seems that for this approach to work, we would need an account of what "intentionally" contributes to “intentionally X-ing” that does not involve one's belief that one is X-ing or will X and does 
not involve one's endeavoring to X. Perhaps such an account can be given, but this is a large question in the philosophy of action, and attempting it is beyond the scope of the inquiry here.

Another way to go when confronted with the problem that one may be untruthful without making a false assertion is to claim that untruthfulness is a matter not of intentionally making a false assertion, but of intentionally making an assertion one believes false.

\section{Intentional Action (Believed-false-version) Analysis:}

$\mathrm{S}$ is untruthful to $\mathrm{H}$ iff:

$\mathrm{S}$ intentionally says something she believes false (is disposed to dissent from) to $\mathrm{H}$.

The idea of this analysis would be that an untruthful assertion is one that the speaker believes to be false, even if it is not in fact false. The analysis can then rely on the notion of doing something intentionally, without having to isolate what is left when doing, endeavoring to do, and believing one will do are subtracted. However, the truth serum case shows that not all untruthful assertions are believed false by the speaker. And the liar serum case shows that some assertions believed false by the speaker are not untruthful. So this analysis faces the same problems as the analysis in terms of intentionally making a false assertion.

\section{Summary and Conclusion}

To sum up the last few sections: believing of one's assertion that it is a false assertion (however this is ultimately cashed out) is neither necessary nor sufficient for the assertion to be untruthful. A more promising idea is that for an assertion to be untruthful is for it to be made with the intention of making a false assertion. This captures cases of untruthfulness in which it is part of the speaker's aim to say something false. However, it does not capture cases of untruthfulness in which this is not part of the speaker's aim. The latter cases push toward analyzing untruthfulness in terms of a speaker intentionally making a false or believed-false assertion. But this cannot be quite right either, if it is possible to make an untruthful assertion that is true (as in a case where the jewel thief tells the interrogators what she thinks is a false location of the jewels but in fact it happens that they are there) or that is not believed-false (as in the truth serum case). It seems that we need to appeal to what is left of intentionally making a false assertion when making a false assertion and aiming to make a 
false assertion are subtracted from it. The obvious thing that seems left is one's belief that one is making a false assertion or will make a false assertion, but we have already seen that this is neither necessary nor sufficient for untruthfulness.

Perhaps we can make the following more limited claim:

An assertion is untruthful only if either:

(i) it is made with the intention of making a false assertion

or

(ii) it is made in/with the belief (which is de-assertion and linked to the act of asserting in some appropriate way that needs spelling out, as discussed above) that it is a false assertion.

This condition is satisfied by Acts of Speech Aimed at Falsity and by typical Acts of Speech Accepting Falsity. Could there be untruthful Acts of Speech Accepting Falsity that are not made in/with the belief that they are false assertions? For instance, could there be a truth serum-type case where the assertion is untruthful although it is neither part of the speaker's aim that it be a false assertion nor does she believe it to be a false assertion?

We can imagine a lazy employee whose boss asks her what she has been doing the past hour. The employee says, "I was working on the report," when in fact she was surfing the Internet. It is not part of the employee's aim in making the assertion that it be a false assertion: her aim is just to tell the boss that she was doing her work. But let us suppose the employee also believes (again, falsely) that the powers-that-be have administered a truth serum to her. If she takes the truth serum to work as described in the previous case, then she does not believe that her assertion will be false as she is making it. Does she believe it is false after she makes it? There seem to be two possibilities. Either she thinks that the truth serum didn't work in this case and her assertion was false, or she thinks that the truth serum did work and she must in fact have been working on the report the past hour, in spite of seeming to remember spending that hour surfing the Internet.

If she thinks after the fact that her assertion was false, is this sufficient for her to satisfy condition (ii)? I think we typically take it that a person might make an assertion truthfully and then come to believe just after she says it that it is false. Perhaps this is incorrect, and any such coming-to-believe does make the assertion untruthful, at least if the speaker does not immediately retract the assertion. This position raises questions, though, about how long one can go without coming to think that one has made a false assertion and still have that assertion be untruthful. Does one have to come to believe the assertion was false within seconds or minutes? Or perhaps the controlling factor is not length of time but whether the 
conversation in which the assertion was made is still going on, or whether the topic of the assertion is still under discussion. This would need working out.

On the other hand, if the ordinary view is correct that a person might make an assertion truthfully and then come to believe just after she says it that it is false, then it would seem that coming to believe one's assertion was false can only put one in danger of, say, failing to retract where one has a duty of some sort to do so. ${ }^{30}$ If this is right, then why should it make the assertion untruthful in the truth serum case?

By contrast, if the employee thinks that the truth serum worked and her assertion must be true in spite of her recollection of slacking, then it seems pretty clear that she does not believe of her assertion that it is false, neither prospectively nor retrospectively. But perhaps in this case the assertion is not untruthful, so it is no counterexample to the necessary condition on untruthful assertion that is under consideration.

The argument for this would be that because the speaker believes her assertion is true after she makes it, it is not untruthful. Suppose the employee tells her boss that she has been working on the report the past hour, thinking that she was surfing the Internet instead, but then comes to believe after she says it that in fact she was working on the report the past hour, while the time spent surfing the Internet was actually during her lunch hour — she just briefly lost track of the order of events. The truth serum case, interpreted in the way suggested, does not seem to be importantly different from this one. And there is some intuitive pull to the idea that the employee in this case does not make an untruthful assertion. However, there is also some pull to the idea that the assertion was untruthful but then the employee changed her mind, allowing her to let her assertion stand. This is parallel to the idea that someone might be truthful but then change their mind, requiring them, perhaps, to retract what they truthfully said. If this latter judgment is correct, then the case stands as a counterexample to the necessary condition on untruthful assertion that is under discussion.

The foregoing discussion suggests, though it does not establish, that the disjunctive intention and belief condition mooted is not even a necessary condition on untruthful assertion, let alone a necessary and sufficient one. (It clearly isn't a sufficient condition because in the liar serum case (ii) is satisfied in the absence of untruthful assertion.)

A satisfactory analysis of untruthfulness, then, requires identifying some aspect of doing something intentionally that is neither (a) actually doing that thing, (b) aiming to do that thing, nor (c) believing that one is doing that thing. The analysis of untruthfulness may after

\footnotetext{
${ }^{30}$ I thank Roy Sorensen for suggesting this to me.
} 
all be held hostage to the analysis of intentional action. That, of course, is too big a project for the present paper. What this paper shows is that the difficulties of analyzing lying include the notion of untruthfulness, which is taken by virtually all extant analyses to be easily treated along the lines of asserting a proposition while believing it is false, or while being disposed to dissent from it. I have tried to show that this kind of analysis is in general unsuccessful, although it may be possible to preserve some version of it by making various other, perhaps undesirable, theoretical commitments. My own feeling is that reflection on untruthfulness leads to larger questions about the nature of intentional action, on which the analysis of lying - not only the ultimate analysis, but the initial analysis at which much work on lying aims-depends.

\section{References}

Anscombe, G. E. M. (1963), Intention, second edition (Blackwell).

Aquinas, T. (1972), 'Question 110: Lying', in Summa Theologiae, Volume 41: Virtues of Justice in the Human Community (McGraw-Hill).

Augustine (1952), 'On Lying,' trans. M. S. Muldowney (pp. 51-110), in R. J. Deferrari (ed.), Fathers of the Church (Volume 16: Treatises on Various Subjects) (Fathers of the Church). Bratman, M. (1987), Intention, Plans, and Practical Reason (Center for the Study of Language and Information).

Carson, T. (2006). 'The Definition of Lying,' in Nô̂s, 40: 284-306.

Chalmers, D. (2012), Constructing the World (Oxford University Press).

Chalmers, D. (2011), 'Propositions and Attitude Ascriptions: A Fregean Account', in Noûs 45 (4): 595-639.

Chalmers, D. (2006), 'The foundations of two-dimensional semantics', in M. Garcia-

Carpintero \& J. Macia (eds.), Two-Dimensional Semantics: Foundations and Applications. (Oxford University Press), 55-140.

Chalmers, D. (2002), 'On Sense and Intension', in Philosophical Perspectives 16 (s16): 135182.

Chalmers, D. (1996), The Conscious Mind: In Search of a Fundamental Theory (Oxford University Press).

Chan, T. and G. Kahane (2011), 'The Trouble with Being Sincere,' in Canadian Journal of Philosophy, 41 (2): 215-234. 
Coleman, L. and P. Kay (1981), 'Prototype Semantics: The English Verb 'lie,' in Language, 57: $26-44$.

Fallis, D. (this volume), 'What is Deceptive Lying?'.

Fallis, D. (2009), 'What is Lying?', in Journal of Philosophy, 106: 29-56.

Faulkner, P. (2013), 'Lying and Deceit,' in H. Lafollette (ed.), International Encyclopedia of Ethics (Wiley-Blackwell), 3101-3109.

Frege, G. (1892/1997), 'On Sinn and Bedeutung', in M. Beaney (ed.) The Frege Reader (Oxford).

Griffiths, P. (2010), Lying: An Augustinian Theology of Duplicity (Wipf and Stock).

Harman, G. (1986), 'Willing and Intending,' in R. E. Grandy and R. Warner (eds.), Philosophical Grounds of Rationality (Oxford University Press), 363-380.

Isenberg, A. (1973). 'Deontology and the Ethics of Lying,' in Aesthetics and Theory of Criticism: Selected Essays of Arnold Isenberg (University of Chicago Press), 245-264. Jackson, F. (1998), 'Reference and description revisited', in Philosophical Perspectives 12 (S12): 201-218.

Kripke, S. (1979), 'A Puzzle About Belief', in A. Margalit (ed.), Meaning and Use (Reidel), 239-83.

Lackey, J. (2013), 'Lies and deception: an unhappy divorce', in Analysis, 73: 236-248.

Mahon, J.E. (2015), 'The Definition of Lying and Deception', in E. N. Zalta (ed.), The Stanford Encyclopedia of Philosophy (Fall 2015 Edition), forthcoming URL = $<$ http://plato.stanford.edu/archives/fall2015/entries/lying-definition/>.

Mahon, J.E. (2008), ‘Two Definitions of Lying', in International Journal of Applied Philosophy, 22: 211-230.

Meibauer, J. (2011), 'On lying: intentionality, implicature, and imprecision,' in Intercultural Pragmatics, 8: 277-292.

Peacocke, C. (1998), 'Conscious Attitudes, Attention, and Self-Knowledge', in C. Wright, B.

C. Smith, and C. MacDonald (eds.), Knowing Our Own Minds (Oxford University Press), 63-98.

Pickard, H. (2004), 'Knowledge of action without observation', in Proceedings of the Aristotelian Society 104 (3): 203-228.

Sainsbury, M. (2010), 'Paderewski Variations', in Dialectica, 64(4): 483-502.

Salmon, N. (1986/1991), Frege's Puzzle (Ridgeview).

Saul, J. (2012), Lying, Misleading, and What Is Said (Oxford University Press).

Setiya, K. (2008), 'Practical Knowledge', in Ethics, 118: 388-409. 
Shiffrin, S. V. (2014), Speech Matters (Princeton University Press).

Sorensen, R. (2011), 'What Lies Behind Misspeaking' in American Philosophical Quarterly 48(4): 399.

Sorensen, R. (2007), 'Bald-Faced Lies! Lying Without The Intent To Deceive' in Pacific Philosophical Quarterly, 88: 251-264.

Stokke, A. (2014), 'Insincerity', in Noûs 48 (3): 496-520.

Stokke, A. (2013), 'Lying and Asserting', in Journal of Philosophy, 110: 33-60. 